J. Perinat. Med. 16 (1988)

\section{Assessment of pulmonary dynamics in normal newborns: a pneumotachographic method}

\author{
Paul Estol, Héctor Píriz, Luis Pintos, Fernando Nieto, and Franco Simini \\ Latin-American Center of Perinatology and Human Development, Montevideo, \\ Uruguay
}

\section{Introduction}

The functional diagnosis of the different forms of respiratory distress in the newborn infant, and assessment of the need for different methods of respiratory assistance, are mainly based on physical examination, X-rays and arterial blood gas analysis.

Mechanical ventilatory assistance is now widely accepted as an effective therapy for respiratory failure in the neonate. Its correct application requires a knowledge of the mechanical abnormalities of the infant's lung. Insufficient ventilatory support can overtax the inadequate ventilatory system of the sick neonate. On the other hand, excessive ventilatory support increases the risk of respiratory complications, such as pulmonary interstitial emphysema, pneumothorax, and bronchopulmonary dysplasia.

At present, ventilatory settings are made by trial and error. Different settings are tried until the desired clinical and arterial blood gas measurements are obtained. This method, though widely used, has important limitations. Firstly, the clinical results are only indirectly related to the physiological variable of the system i.e. pulmonary ventilation. Secondly, blood gas analysis being intermittent does not easily allow one to appreciate trends nor abrupt changes in the respiratory state of the neonate.

To achieve better knowledge of the mechanical variables involved in the different forms of respiratory distress of the newborn infant, we have developed a pneumotachographic method to determine pulmonary dynamics in newborns. This

\section{Curriculum vitae}

Paul Estol M.D., was born in 1952. He graduated as a medical doctor at the Faculty of Medicine of Montevideo, Uruguay in 1981. Since 1979 he has worked in perinatal investigation at the Faculty of Medicine of Montevideo and at the Centro Latinoamericano de Perinatología (PAHO/WHO). His

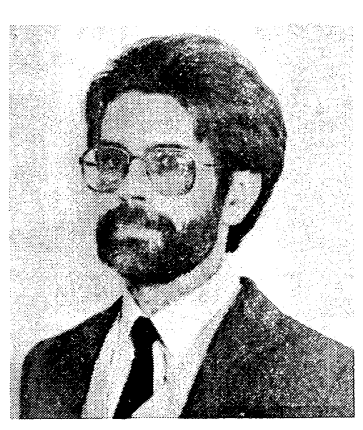
special interest include fetal and neonatal respiratory physiology. Since 1982 he has worked as a clinical neonatologist in the Neonatal Intensive Care Unit of the Faculty of Medicine of Montevideo, Uruguay, and since 1984 he has been a neonatologist of the Centro Latinoamericano de Perinatología (PAHO/WHO). The present project has been developed in, and with the assistance of both institutions.

helps to make a functional diagnosis and to select treatment in those cases needing mechanical ventilation.

Before the results obtained with this method can be applied, the normal neonatal range has to be established. Information concerning normal pulmonary dynamics of the newborn has been available since the early ' $50 \mathrm{~s}$, but most of these are from studies performed using plethysmographic methods, which are not comparable to the method we have used. Thought two reports used a pneumotachographic method [11, 12], the results still should not be compared, due to minor technical 
differences. The comparison of results obtained with a given method, against the "normal values" obtained with a different method, may be cause of error, and result in false conclusions.

We have determined the pulmonary dynamic data of a group of term and preterm normal infants in order to establish the range of normal values with our method, and to compare them with the results obtained by other authors. These values will be of great assistance in the interpretation of results encountered in infants with respiratory distress, when using this instrumentation.

\section{Material and methods}

Normal term and preterm newborns, born at the Clínica Ginecotocológia "B" of the Faculty of Medicine in Uruguay, in the period between March 1984 and December 1985 were studied. Informed consent was obtained from the mother prior to performing any measurement in the newborn. They were admitted to the neonatal intensive care unit where all studies were carried out and were examined by a neonatologist (one of the authors). Newborns with any pathology were not included in the study. The measurements were made with the infants prone or supine nursed in the same conditions as they had been just before. All infants breathed air during the determinations. More than 1 hour had elapsed since the last feed. A water-filled, sterile, end hole polyethylene catheter, was placed in the lower third of the esophagus. This was connected to a Sanborn Model 269A pressure transducer, to record esophageal pressure (Pes) (figure 1). Patency was maintained with an intraflow (R) system using a continuous flow of sterile distilled water. Once the baby tolerated the esophageal catheter, a pair of nasal prongs normally used for continuous positive pressure, or an inflatable face mask were gently applied. The baby would initially react adversely, but in a few minutes, would grow accustomed and finally breathe regularly. The prongs or mask were connected to an electrically heated grid pneumotachograph, constructed in our laboratory, and attached to a differential pressure transducer (Sanborn Model $\mathrm{N}^{\circ} 270$ ) with which airflow $(\mathrm{F})$ was measured in a range of 0 to $198 \mathrm{ml} / \mathrm{s}$.

The flow signal was electronically integrated with time, using an integrator constructed in our laboratory. A volume signal (V) was produced (figure 1). At the nasal prongs, or at the face mask, distal to the pneumothacograph, an opening in the lumen of the system allowed the passage of a catheter attached to a model 268B Sanborn pressure transducer used to assess the airway pressure (Paw) (figure 1). These four signals: F, V, Paw, Pes, were simultaneously recorded on a Sanborn 7700 Series multichannel recorder (figure 1). Once all components were connected, and adequate signals were obtained on the recorder, we waited until the newborn entered a period of regular

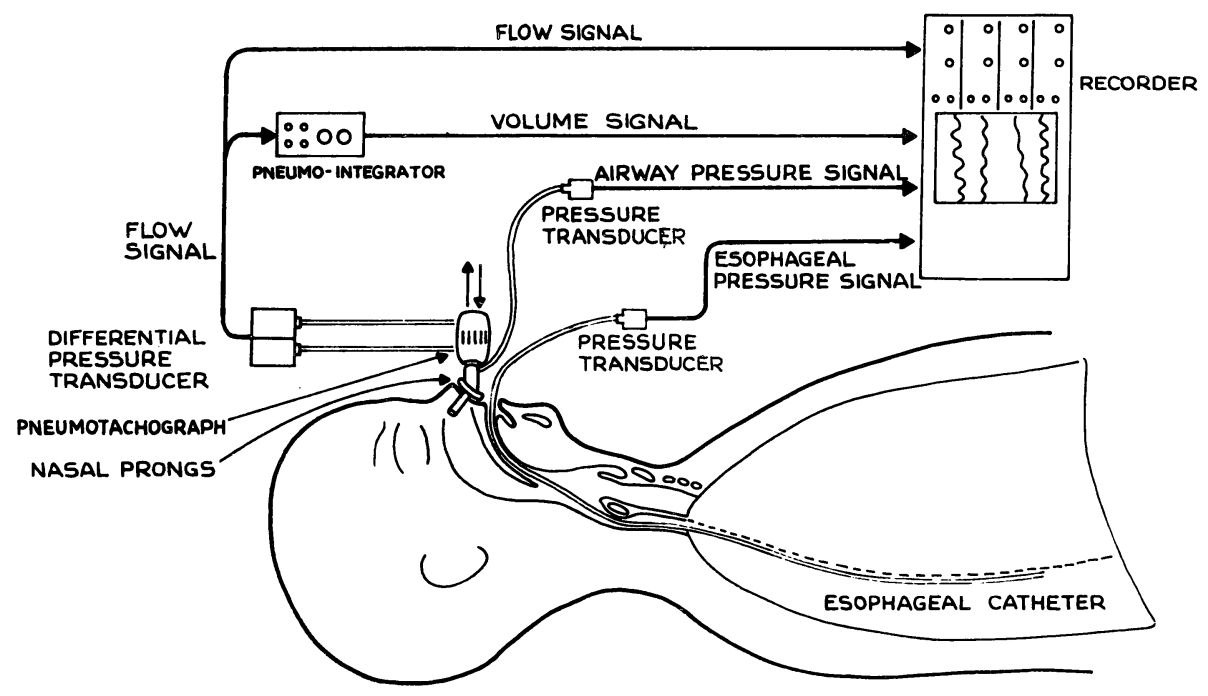

Figure 1. Pneumotachographic method used in the determination of pulmonary dynamic data. 


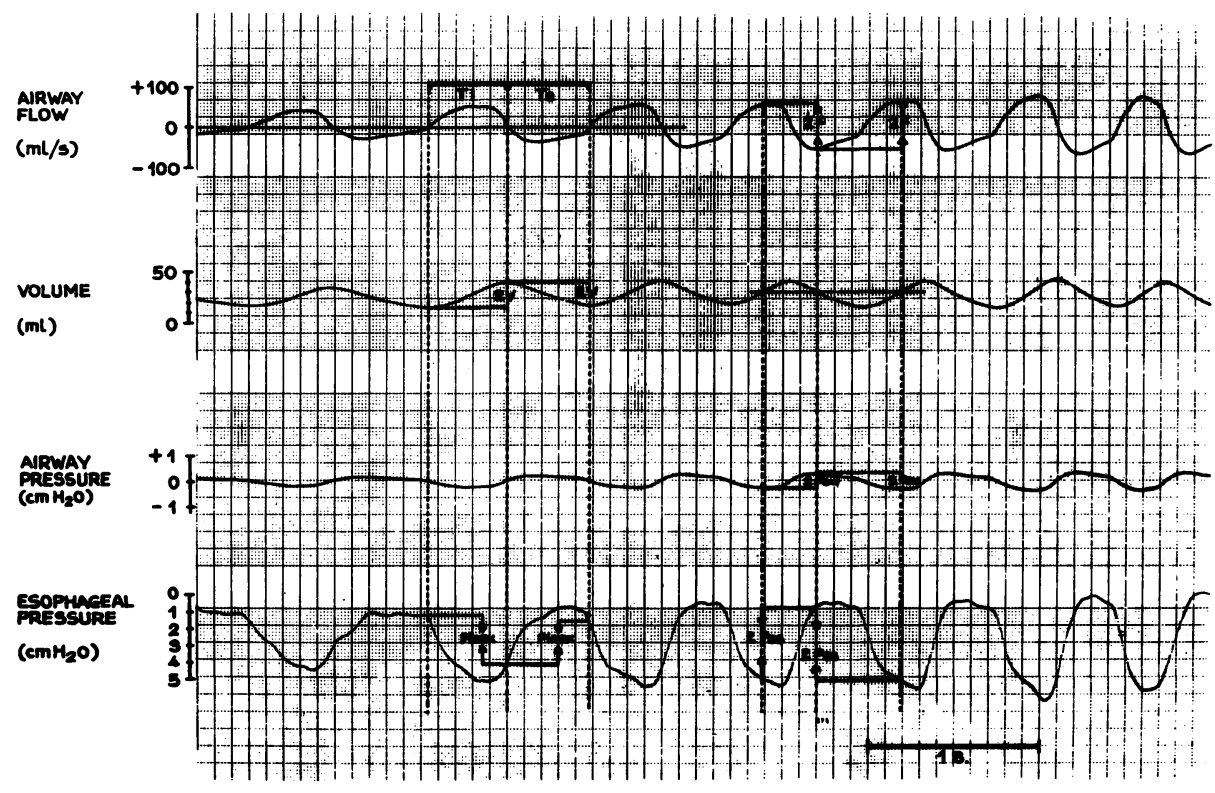

Figure 2. Tracing of flow (F), volume (V), airway pressure (Paw) and esophageal pressure (Pes), obtained at a speed of $50 \mathrm{~mm} / \mathrm{s}$.

respiration, usually in quiet sleep. When a regular pattern of respiration was present, the recorder was started using a chart paper speed of $50 \mathrm{~mm} /$ s. Ten successive respiratory cycles were recorded in which the following variables were determined (figure 2).

\subsection{Breathing frequency (1)}

$\mathrm{T}$ is the cycle duration which is taken to be the time interval separating the start of successive breathing cycles. The start of a breath is defined as the positive deflection from zero on the air flow record.

$\bar{T}$ is the mean of 10 determinations of $T$. $T$ is given in seconds.

$\mathrm{f}$, the respiratory frequency, is calculated by:

$$
\begin{aligned}
\mathrm{f} & =60(\mathrm{~s} / \mathrm{min}) / \overline{\mathrm{T}}(\mathrm{s}) \\
& =60 / \overline{\mathrm{T}}(1 / \mathrm{min})
\end{aligned}
$$

\subsection{Tidal volume and dynamic compliance (Cdyn)}

Dynamic compliance can be thought of as the ability of the respiratory system to store energy to be used later in the cycle. It is estimated by the ratio of the tidal volume and the esophageal pressure at moments of zero flow. On the air flow record, all points of zero flow are marked. They alternately represent end-expiration and end-inspiration. These are projected on the volume record and on the esophageal pressure record (figure 2).

$\mathrm{V}$ is the amplitude of the volume record. $2 \mathrm{~V}$ is the peak to peak excursion measured between the end-inspiration and end-expiration points.

$\mathrm{VT}$, is the tidal volume, and is the mean of 10 determinations of $2 \mathrm{~V}$. VT is expressed in $\mathrm{ml}$.

Pinex is the excursion of the esophageal pressure record taken between end inspiration and end expiration points.

Pinex is the mean of 10 determinations of Pinex. Pinex is expressed in $\mathrm{cm}_{2} \mathrm{O}$.

Cdyn, the dynamic compliance, is calculated by:

$$
\text { Cdyn }=\text { VT/P̄inex }\left(\mathrm{ml} / \mathrm{cmH}_{2} \mathrm{O}\right)
$$

\subsection{Minute ventilation ( $(\dot{\mathrm{V}})$}

Having determined $f$, the respiratory frequency, and VT, then the minute ventilation $V$ is given by:

$$
\dot{\mathrm{V}}=\mathrm{f} \mathrm{VT}(\mathrm{ml} / \mathrm{min})
$$

\subsection{Total pulmonary resistance $(R)$}

Total pulmonary resistance, $R$, can be thought of as the ratio between a driving force and the result- 
ing air flow, assuming no mechanical energy is stored during part of the cycle. The driving force is the difference between the pressure in the airway and the pressure in the esophagus. Since all the signals considered are periodic we represent them for simplicity as purely sinusoidal to estimate R. $\mathrm{R}$ is given by the ratio of the pressure difference amplitude and the airflow amplitude. We chose the airflow signal as the reference, since it approximates to a sinusoidal signal better than the pressure signals (figure 2). The points of maximum and minimum flow are determined easily by the mid points of the volume signal. These points are taken to represent zero, though the value is positive because of the integration constant.

$\mathrm{F}$ is the amplitude of the airflow signal between successive mid volume points (figure 2).

$\bar{F}$ is the mean of 10 determinations of $F$.

Pes is the amplitude of the esophageal pressure signal. 2 Pes is the peak to peak excursion measured between successive mid volume points (figure 2).

Pes is the mean of 10 determinations of Pes.

Paw is the amplitude of the airway pressure signal. 2 Paw is the peak to peak excursion measured between successive mid volume points (figure 2). $\overline{\mathrm{P}} \mathrm{aw}$ is the mean of 10 determinations of Paw. $\mathrm{R}$ is calculated by:

$$
\mathrm{R}=(\overline{\mathrm{P}} \mathrm{es}-\overline{\mathrm{P}} \mathrm{aw}) / \overline{\mathrm{F}} \quad\left(\mathrm{cm} \mathrm{H} \mathrm{H}_{2} \mathrm{O} / \mathrm{l} / \mathrm{s}\right)
$$

$\mathrm{R}$ represents the amplitude pressure difference needed to obtain a flow of 1 litre per second.

\subsection{Respiratory work}

The mechanical energy necessary to perform one breathing cycle is called "total respiratory work". It is given by the mathematical integration, over the duration of one cycle, of the product of the difference of pressure (airway and esophagus) and the resulting airflow signal.

It is customary to ignore the airway pressure which is an order of magnitude smaller than the esophageal pressure. Therefore the work is given by the integral of flow and esophageal pressure:

$$
\mathrm{W}=\text { integral } \dot{\mathrm{V}} \text { Pes dt }\left(\mathrm{cm} \mathrm{H}_{2} \mathrm{O} \mathrm{min} \mathrm{ml} / \mathrm{min}\right)
$$

But $\dot{\mathrm{V}} \mathrm{dt}$ is the time differential of the volume signal:

$$
\mathrm{dV}=\dot{\mathrm{V}} \mathrm{dt}
$$

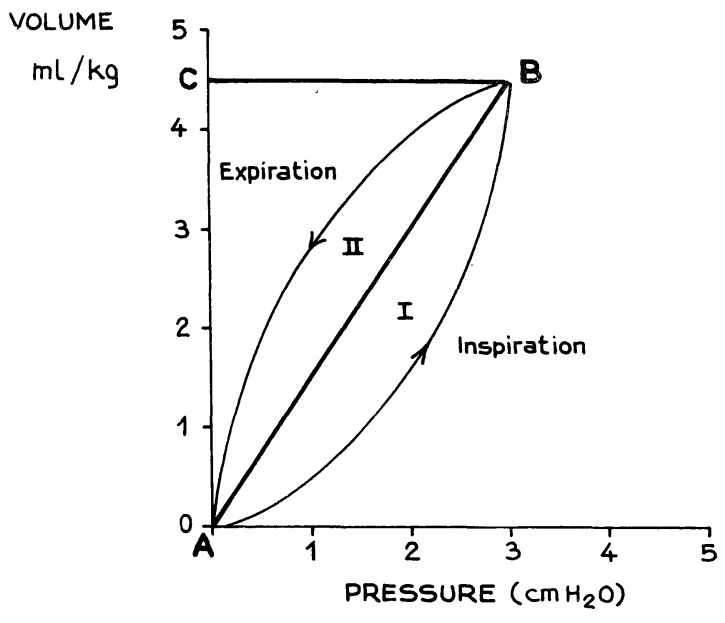

Figure 3. Pressure-volume loop. Area $A B C$ represents elastic respiratory work (We). Area enclosed in the loop represents inspiratory (I) and expiratory (II) flow resisting work (Wv). Assuming that expiration is passive, total pulmonary work (Wt) is represented by the sum of elastic work (We) plus inspiratory flow resistive work (I).

In other words, work can be estimated as the integral of Pes with respect to $\mathrm{V}$ instead of with respect to time $\mathrm{t}$ :

$$
\mathrm{W}=\text { integral Pes } \mathrm{dV}
$$

The representation of a breathing cycle showing Pes as a function of $\mathrm{V}$ is known as a pressurevolume loop (figure 3). The area $\mathrm{ABC}$ represents the elastic respiratory work (We). The area enclosed in the pressure volume loop, represents inspiratory (I) and expiratory (II) flow resistive work (Wv) performed during the respiratory cycle. Assuming that expiration is passive, total pulmonary work $(\mathrm{Wt})$ is represented by the sum of elastic work (triangle ABC), plus the inspiratory flow resistive work (I) [6]. These respective areas were calculated with a disc roller planimeter. The obtained value, when multiplied by frequency and divided by 60 , gave the energy consumed per second, which was expressed in $\mathrm{mW}$. This value is represented, so as to facilitate comparison as $\mathrm{mW}$ divided by minute ventilation $(\mathrm{mW} / \mathrm{V})$.

Tidal volume, minute ventilation, dynamic compliance and total pulmonary resistance were linearly correlated with body weight using a multiple regression method. A critical value of alpha less than 0.05 was considered as significant. 
The values of tidal volume (VT), minute ventilation (V), and dynamic compliance (Cdyn) were corrected for body weight. The mean $(\overline{\mathrm{X}})$ and standard deviation (SD) were calculated for each variables as well as the 10th and 90th percentiles, using a table of $\mathrm{Z}$ values.

Before each study, all signals were calibrated, $F$ with an electric signal, $V$ with a $50 \mathrm{ml}$ glass syringe, and pressure with a water manometer.

\section{Results}

A total of 51 records were obtained in 48 newborns. In three infants two records each were obtained, after an interval of one week. The post-

Table I. Corrected gestational age of the infants at the times they were studied

\begin{tabular}{cc}
\hline $\begin{array}{l}\text { Gestational age } \\
\text { (weeks) }\end{array}$ & $\begin{array}{l}\text { Records } \\
(\mathrm{n})\end{array}$ \\
\hline$\gtrless 30$ & 2 \\
$31-34$ & 9 \\
$35-36$ & 8 \\
$>37$ & 32 \\
\hline
\end{tabular}

Table II. Body weight of the infants at the times they were studied

\begin{tabular}{lc}
\hline $\begin{array}{l}\text { Body weight } \\
(\mathrm{g})\end{array}$ & $\begin{array}{l}\text { Records } \\
(\mathrm{n})\end{array}$ \\
\hline $1000-1499$ & 6 \\
$1500-1999$ & 9 \\
$2000-2499$ & 11 \\
$2500-2999$ & 5 \\
$3000-3499$ & 12 \\
$>3500$ & 8 \\
\hline
\end{tabular}

natal age of the newborns when studies were performed ranged between 24 hours and 21 days. Nineteen records were obtained in preterm $(<37$ weeks gestational age) and 32 in term infants. The corrected gestational ages of the infants at the time of the study is shown in table I.

Twenty six records were obtained in low birth weight infants $(<2500 \mathrm{~g})$, and 25 in infants weighing more than $2500 \mathrm{~g}$. The body weights of the infants at the time of the study are shown in table II.

Tidal Volume (VT): No significant correlation was found between VT and body weight $(\mathrm{r}=0.20$, NS) (figure 4). The $\mathrm{VT} / \mathrm{Kg}$ in the 51 records was $6.28 \pm 3.17 \mathrm{ml} / \mathrm{Kg}(\overline{\mathrm{X}} \pm \mathrm{SD})$, with the 10 th centile 2.21 and the 90th centile 10.34 (table III, figure 4).

Minute ventilation $(\dot{V})$ : No correlation was found between $\dot{V}$ and body weight $(r=0.17$, NS) (figure 4). The $\dot{\mathrm{V}} / \mathrm{Kg}$ in the 51 records was $425.3 \pm 220.3$ $\mathrm{ml} / \mathrm{min} / \mathrm{Kg}$, with the 10 th centile 142.9 and the 90th centile 707.7 (table III, figure 4).

Dynamic compliance (Cdyn): A positive correlation was obtained between Cdyn and body weight $(\mathrm{r}=0.50, \mathrm{p}<0.01$ ) (figure 4). The $\mathrm{Cdyn} / \mathrm{Kg}$ body weight value in the 51 records was 1.57 $\pm 0.57 \mathrm{ml} / \mathrm{cm} \mathrm{H}_{2} \mathrm{O} / \mathrm{Kg}$, with the 10 th centile 0.84 and the 90 th centile 2.30 (table III, figure 4).

Total pulmonary resistance $(\mathrm{R})$ : No correlation was found between $R$ and body weight $(r=0.16$, NS) (figure 4). The $R$ value in the 51 records was $51.1 \pm 26.1 \mathrm{cmH}_{2} \mathrm{O} / \mathrm{l} / \mathrm{s}$, with the 10 th centile 17.6 and the 90th centile 85.6 (table III, figure 4).

Total respiratory work $(\mathrm{Wt})$ : Determination of respiratory work was only performed in 40 of the 51 records. The $\mathrm{Wt}$ in these 40 records was 8.65 $\pm 3.59 \mathrm{~mW} / \mathrm{l} / \mathrm{Kg} / \mathrm{min}$, with the 10 th centile 4.05 and the 90th centile 13.25 (table III).

Table III. Values for pulmonary dynamics in a population of term and preterm infants

\begin{tabular}{|c|c|c|c|c|}
\hline & $\mathrm{n}$ & $\overline{\mathrm{x}} \pm \mathrm{SD}$ & 10th centile & 90th centile \\
\hline Tidal volume $(\mathrm{VT})(\mathrm{ml} / \mathrm{Kg})$ & 51 & $6.28 \pm$ & 2.21 & 10.34 \\
\hline Minute ventilation $(\dot{\mathrm{V}})(\mathrm{ml} / \mathrm{min} / \mathrm{Kg})$ & 51 & $425.3 \pm 220.3$ & 142.9 & 707.7 \\
\hline Dynamic compliance $(\mathrm{Cdyn})\left(\mathrm{ml} / \mathrm{cmH}_{2} \mathrm{O} / \mathrm{Kg}\right)$ & 51 & $1.57 \pm 0.57$ & 0.84 & 2.30 \\
\hline Total pulmonary resistance $\left(\mathrm{cmH}_{2} \mathrm{O} / 1 / \mathrm{s}\right)$ & 51 & $51.1 \pm$ & 17.6 & 85.6 \\
\hline Total work $(\mathrm{Wt})(\mathrm{mW} / \mathrm{l} / \mathrm{Kg} / \mathrm{min})$ & 40 & $8.65 \pm$ & 4.05 & 13.25 \\
\hline Elastic work (We) (mW/1/Kg/min) & 40 & $4.91 \pm$ & 2.19 & 7.63 \\
\hline Flow resistive work $(\mathrm{Wv})(\mathrm{mW} / \mathrm{l} / \mathrm{Kg} / \mathrm{min})$ & 40 & $6.11 \pm$ & 2.49 & 9.73 \\
\hline
\end{tabular}




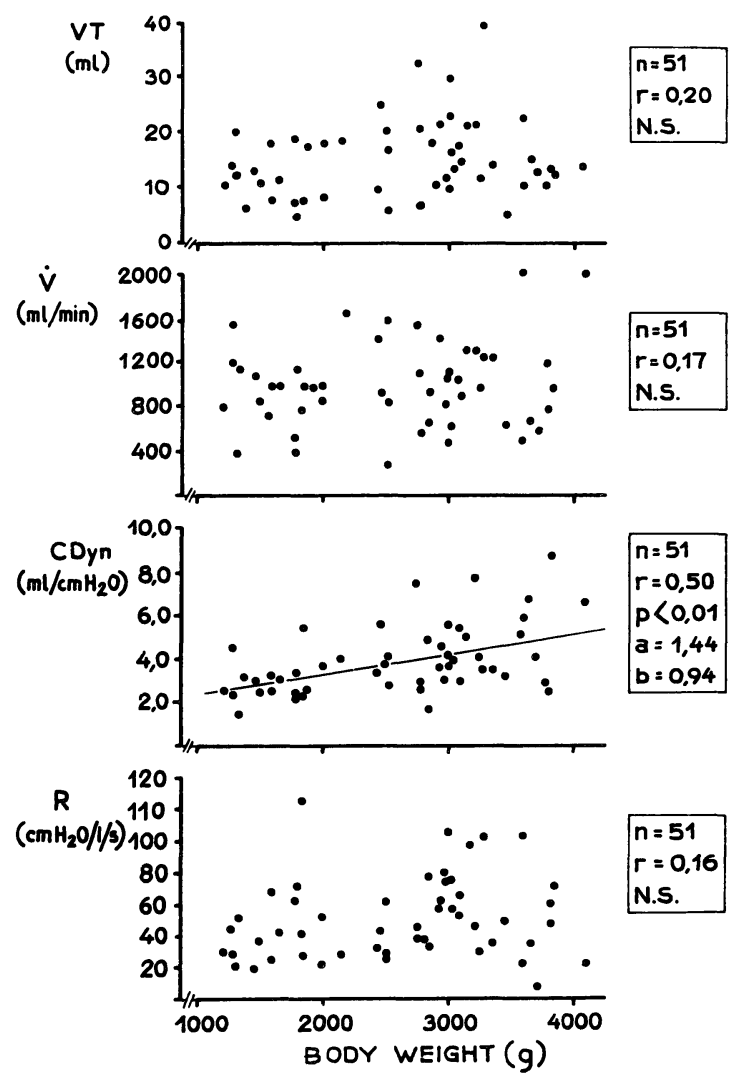

Figure 4. Values for VT, Cdyn and R correlated against body weight.

Elastic work (We): In these 40 records elastic work was $4.91 \pm 2.12 \mathrm{~mW} / \mathrm{l} / \mathrm{Kg} / \mathrm{min}$. with the 10 th centile 2.19 and the 90 th centile 7.63 (table III).

Flow resistive work (Wv): In these 40 records flow resistive work was $6.11 \pm 2.82 \mathrm{~mW} / 1 / \mathrm{Kg} / \mathrm{min}$ with the 10 th centile 2.49 and the 90 th centile 9.73 (table III).

\section{Discussion}

The determination of a normal range of values of pulmonary dynamics in newborns is a necessary first step toward the correct interpretation of those results obtained using new techniques in infants with respiratory distress.

Although various reports of pulmonary dynamics in normal newborns have been published to date (table IV), only 2 of them have used a pneumotachographic method $[11,12]$. In both reports, al- though the volumes are determined in a similar way, the assessment of esophageal pressure is performed using a catheter with a latex balloon, which could have produced different results from our study which employed a water-filled catheter.

The values for $\mathrm{Cdyn} / \mathrm{Kg}$ found in the present study $\left(1.57 \pm 0.57 \mathrm{ml} / \mathrm{cmH}_{2} \mathrm{O} / \mathrm{Kg}\right)(\overline{\mathrm{X}} \pm \mathrm{SD})$ are similar to those found by SwYER et al. [11] (1.69 $\pm 0.62)$ and by Yu et al. [12] (1.65 \pm 0.16$)$, both using a pneumotachographic method. Our values for resistance $\left(51.6 \pm 26.1 \mathrm{~cm} \mathrm{H} \mathrm{H}_{2} \mathrm{O} / \mathrm{l} / \mathrm{s}\right)$ are somewhat higher than those found by SwYER et al. [11] (26.4 \pm 12.9$)$, but similar to those found by Yu et al. [12] (44. \pm 5.2). The values for $\mathrm{VT} / \mathrm{Kg}$ are very similar to these three reports in which pneumotachographic is used. We have found a greater value for $\dot{V} / \mathrm{Kg}$, than those reported by the previously mentioned authors. It also is greater when compared with other authors who used plethismography $[3,5,7]$. Some of the possible explanations for this finding are:

1) Excessive dead space in those cases in which a face mask was used.

2) The effect of the nocioceptive stimulus produced by an inadequate application of the face mask or nasal prongs to the infant's face.

3) Inappropriate choice of the time the recording was made.

A time period which comprises only 10 cycles is very short and may easily be unrepresentative of what happens under basal conditions. Minute volumes in this study cannot be considered as basal. Minimal minute volumes may not be reached until the infant has been asleep for periods greater than 1 Hour [11]. This is supported by the fact that in our study the 31 infants in whom a face mask was used had a $\dot{V} / \mathrm{Kg}$ of $534,2 \pm 210,6$ $\mathrm{ml} / \mathrm{Kg} / \mathrm{min}$. ( $\bar{X} \pm \mathrm{SD}$ ), which was significatively higher than that found in the 20 infants in whom nasal prongs were used $(265.5 \pm 90.0 \mathrm{ml} / \mathrm{min} / \mathrm{Kg})$ $(\mathrm{t}=5.56, \mathrm{p}<0.005)$. This could also explain the unexpected lack of correlation found between $\dot{V}$ and VT with body weight.

Once these results were obtained, we discarded the face mask and used only nasal prongs. We also started to take greater precautions with their application to the infant's nose, at the time we made our recordings. Our $\dot{\mathrm{V}} / \mathrm{Kg}$ and $\mathrm{VT} / \mathrm{Kg}$ values should thus be interpreted with caution.

Our results are encouraging because our values of $\mathrm{Cdyn} / \mathrm{Kg}, \mathrm{R}$ and $\mathrm{VT} / \mathrm{Kg}$ are in accord with those 
Table IV. Pulmonary dynamic values reported in the literature, and recalculated with correction for body weight. (S. G. A. = Small for Gestational Age)

(All values are $\overline{\mathrm{X}} \pm 1$ S. D.)

\begin{tabular}{|c|c|c|c|c|c|c|}
\hline Author & Method & Population & $\begin{array}{l}\mathrm{Vt} \\
(\mathrm{ml} / \mathrm{Kg})\end{array}$ & $\begin{array}{l}\dot{\mathrm{V}} \\
(\mathrm{ml} / \mathrm{Kg} / \mathrm{min})\end{array}$ & $\begin{array}{l}\text { Cdyn } \\
\left(\mathrm{ml} / \mathrm{Kg} / \mathrm{cmH}_{2} \mathrm{O}\right)\end{array}$ & $\begin{array}{l}\mathrm{R} \\
\left(\mathrm{cmH}_{2} \mathrm{O} / 1 / \mathrm{s}\right)\end{array}$ \\
\hline $\begin{array}{l}\text { CooK } \\
\text { [3] }(1956)\end{array}$ & $\begin{array}{l}\text { Body ple- } \\
\text { thysmograph, } \\
\text { water filled } \\
\text { esophageal } \\
\text { catheter }\end{array}$ & $\begin{array}{l}26 \text { normal new- } \\
\text { borns, } \\
2400-3800 \mathrm{~g} \text {, } \\
14 \text { hours to } 7 \text { days } \\
\text { old, } 38 \text { records }\end{array}$ & $5.42 \pm 1.49$ & $243.2 \pm 118.4$ & $1.60 \pm 0.63$ & $37.3 \pm 24.4$ \\
\hline $\begin{array}{l}\text { SWYER } \\
\text { [11] (1960) }\end{array}$ & $\begin{array}{l}\text { Pneumotacho- } \\
\text { graph, water } \\
\text { filled esophageal } \\
\text { catheter }\end{array}$ & $\begin{array}{l}15 \text { normal infants, } \\
2 \text { hours to } \\
12 \text { days age, } \\
2410 \text { to } 3960 \mathrm{~g}\end{array}$ & $6.96 \pm 1.83$ & $240.0 \pm 43.8$ & $1.69 \pm 0.62$ & $26.4 \pm 12.9$ \\
\hline $\begin{array}{l}\text { PolgaR } \\
\text { [8] (1961) }\end{array}$ & $\begin{array}{l}\text { Body ple- } \\
\text { thysmograph, } \\
\text { esophageal } \\
\text { balloon }\end{array}$ & $\begin{array}{l}15 \text { normal new- } \\
\text { borns, } 6 \text { hours } \\
\text { to } 17 \text { days old, } \\
1980 \text { to } 4500 \mathrm{~g}\end{array}$ & - & - & $1.94 \pm 0.70$ & $\begin{array}{l}18.1 \pm 5.86 \\
\text { (Airway } \\
\text { resistance) }\end{array}$ \\
\hline $\begin{array}{l}\text { KARLBERG } \\
\text { [7] (1962) }\end{array}$ & $\begin{array}{l}\text { Reverse } \\
\text { plethys- } \\
\text { mography }\end{array}$ & $\begin{array}{l}23 \text { normal new- } \\
\text { borns, } 1290 \text { to } \\
4499 \mathrm{~g}, 2 \text { hours } \\
\text { to } 8 \text { days old, } \\
42 \text { records }\end{array}$ & $0.34 \pm 2.57$ & - & $1.53 \pm 0.63$ & $35.6 \pm 24.0$ \\
\hline $\begin{array}{l}\text { CHU } \\
\text { [2] (1964) }\end{array}$ & $\begin{array}{l}\text { Body ple- } \\
\text { thysmograph, } \\
\text { esophageal } \\
\text { latex balloon }\end{array}$ & $\begin{array}{l}62 \text { normal new- } \\
\text { borns, } 8 \text { hours to } \\
55 \text { days old, } \\
1130 \text { to } 4360 \mathrm{~g}\end{array}$ & - & - & $\begin{array}{l}\text { Range of } \\
1.6 \pm 0.5 \text { to } \\
2.2 \pm 0.3\end{array}$ & - \\
\hline $\begin{array}{l}\text { PolGAR } \\
\text { [9] (1965) }\end{array}$ & $\begin{array}{l}\text { Body ple- } \\
\text { thysmograph, } \\
\text { esophageal } \\
\text { latex balloon }\end{array}$ & $\begin{array}{l}10 \text { normal new- } \\
\text { borns, } \\
3-60 \text { hours old } \\
3033 \text { to } 3850 \mathrm{~g}\end{array}$ & - & - & $1.77 \pm 0.42$ & $34.1 \pm 8.9$ \\
\hline $\begin{array}{l}\text { BARRET- } \\
\text { DAHMS } \\
\text { [1] (1974) }\end{array}$ & $\begin{array}{l}\text { Wedge spiro- } \\
\text { meter, water } \\
\text { filled esophageal } \\
\text { catheter }\end{array}$ & $\begin{array}{l}9 \text { S. G. A. infants, } \\
6 \text { hours to } \\
7 \text { days old, } \\
1077 \text { to } 2100 \mathrm{~g}\end{array}$ & - & - & $2.72 \pm 2.12$ & $99.6 \pm 57.6$ \\
\hline $\begin{array}{l}\text { HJAL- } \\
\text { MARSON } \\
\text { [5] (1974) }\end{array}$ & $\begin{array}{l}\text { Body ple- } \\
\text { thysmograph, } \\
\text { esophageal } \\
\text { balloon }\end{array}$ & $\begin{array}{l}49 \text { normal infants, } \\
>12 \text { hours to } \\
21 \text { days old, } \\
1310 \text { to } 4750 \mathrm{~g}\end{array}$ & $6.6 \pm 2.35$ & $335 \pm 125$ & $1.65 \pm 0.55$ & $46 \pm 17$ \\
\hline $\begin{array}{l}\text { YU } \\
\text { [12] (1976) }\end{array}$ & $\begin{array}{l}\text { Pneumotacho- } \\
\text { graph with } \\
\text { nasal adaptor, } \\
\text { esophageal } \\
\text { balloon }\end{array}$ & $\begin{array}{l}12 \text { normal infants, } \\
5 \text { to } 72 \text { hours old, } \\
\text { body weight } \\
2555 \pm 229 \text { g, } \\
\text { pre feeding values }\end{array}$ & $5.9 \pm 0.2$ & $259 \pm 16$ & $1.65 \pm 0.16$ & $44 \pm 5.2$ \\
\hline
\end{tabular}

found by other authors who used both similar $[11,12]$ and different methods $[3,5,7]$. This allows us to continue with the second stage of our program of respiratory studies in newborns, that is to apply this method in the study of infants with respiratory distress and use for the adjustment of ventilatory settings in neonates who require assisted ventilation. 
Whole body plethysmography has been one of the most frequently used methods in newborn studies, but its widespread utilization has been hindered by difficulties in applying it in the study of distressed infants whe are dependent on complex systems of life support. This is not the case with pneumotachography, in which the pneumotachograph is placed between the ventilator and the endotracheal tube adaptor and this with the placing of an esophageal catheter, are the two only maneuvers performed on the infant. This minimal manipulation, together with the development of biological signal processing with microprocessors and "on line" computing systems [4], place the pneumotachographic method as best suited for pulmonary dynamic data assessment in infants in the neonatal intensive care unit who have severe distress.

\section{Summary}

A pneumotachographic method for assessment of pulmonary dynamics in critically ill newborns in an intensive care setting was developed in our laboratory. Before the results obtained with this method could be applied, the normal range of values were determined in 48 normal term and preterm newborns. Their body weight ranged between 1200 and $4100 \mathrm{~g}$, and postnatal ages between 24 hours and 21 days. In three infants, two determinations were performed after an interval of 7 days. The studies were performed with a pneumotachograph applied to the upper airway by means of an inflatable face mask or latex nasal prongs. The air flow signal was electronically integrated to time to produce a volume signal. Airway pressure was determined proximal to the pneumotachograph. Esophageal pressure was determined with a water filled catheter placed in the lower third of the esophague.

Tidal volume (VT), minute ventilation ( $\dot{V})$, Dynamic compliance (Cdyn), total pulmonary resistance (R), total pulmonary work (Wt), Elastic work (We), and flow resistive work (Wv), were determined.

A significant linear correlation was found between Cdyn and body weight $(r=0.50, p<0.01)$ whereas no significative correlation was found between body weight and

VT, $\dot{V}$ or R. Values for VT, $\dot{V}$ and Cdyn were corrected for body weight and means $(\overline{\mathrm{X}})$, standard deviation (SD) so as 10 th and 90th percentiles are shown in table III. $\overline{\mathrm{X}}, \mathrm{SD}$ and percentiles for $\mathrm{R}$ were shown in table III. $\mathrm{Wt}$, We and $\mathrm{Wv}$ were corrected for $\dot{\mathrm{V}}$, and $\overline{\mathrm{X}}, \mathrm{SD}$ and percentiles shown in table III. Values of VT/Kg, Cdyn/ $\mathrm{Kg}$ and $\mathrm{R}$ are similar to those found by other authors with pneumotachography and plethysmography.

The $\dot{V} / \mathrm{Kg}$ values obtained by us were higher than those reported by other authors, which together with the lack of correlation of VT and $\dot{V}$ with body weight, question the reliability of $\dot{V}$ values in our study. This could be explained by:

1) excessive increase in dead space in cases in which a face mask was used;

2) nocioceptive stimulus produced by face mask or nasal prongs;

3) inadequate selection of the moment at which the record was obtained.

Whichever the explanation, our values of $\dot{V}$ cannot be considered as basal, and should be interpreted with caution. The results obtained allow us to continue with our program and apply this method to the study of newborn infants with RDS.

Keywords: Lung, newborn, pulmonary dynamics.

\section{Zusammenfassung}

Bestimmung der Lungendynamik bei gesunden Neugeborenen durch Pneumotachographie

Wir entwickelten eine pneumotachographische Methode zur Bestimmung der Lungendynamik bei schwerkranken, intensivüberwachten Neugeborenen. Bevor diese Methode angewendet werden kann, ist die Erhebung von Normalwerten an einem gesunden Kollektiv notwendig. Dieses bestand aus 48 Reif- und Frühgeborenen mit einem Geburtsgewicht zwischen 1200 und $4100 \mathrm{~g}$ im Alter zwischen $24 \mathrm{~h}$ und 21 Tagen. Bei 3 Kindern wurden jeweils 2 Messungen im Abstand von 7 Tagen durchgeführt. Der Pneumotachograph wurde mittels einer aufblasbaren Gesichtsmaske oder Latex-,„Nasenspitzen“ mit den oberen Luftwegen verbunden und das FlowSignal wurde elektronisch über die Zeit integriert zur

Erstellung eines Volumensignals. Der Druck in den Luftwegen wurde proximal des Pneumotachographen abgeleitet, der Ösophagusdruck mit einem wassergefüllten Katheter im unteren Speiseröhrendrittel gemessen.

Bestimmt wurden Strömungsvolumen (VT), Minutenventilation ( $\dot{\mathrm{V}})$, dynamische Compliance (Cdyn), Atemwegswiderstand $(\mathrm{R})$, Atmungsarbeit (Wt), elastische Arbeit (We) und Strpmungswiderstand (Wv).

Zwischen Cdyn und Geburtsgewicht fand sich eine signifikante lineare Korrelation $(r=0.50, p<0.01)$, jedoch keine zwischen Geburtsgewicht und VT, $\dot{V}$ oder R. Die Werte für VT, $\dot{V}$ und Cdyn wurden für das Geburtsgewicht korrigiert, Tabelle III zeigt Mittelwerte $(\overline{\mathrm{X}})$, die Standardabweichung (SD) sowie die 10er und 90er Perzentile und ebenso die Kurven für R. Weiterhin zeigt 
Tabelle III die Mittelwerte, Standardabweichung und Perzentilen für Wt, We und Wv nach Korrektur für $\dot{V}$. Die Werte VT/kg, Cdyn $/ \mathrm{kg}$ und $\mathrm{R}$ sind denen anderer Autoren, die mit Pneumotachographie und Plethysmographie gearbeitet haben, vergleichbar.

Die $\dot{V} / \mathrm{kg}$-Werte sind in unserer Studie größer als die anderer Autoren. Zusammen mit der fehlenden Korrelation zwischen VT und $\dot{V}$ und dem Geburtsgewicht muß die Reliabilität der $\dot{V}$-Werte unserer Studie angezweifelt werden. Mögliche Erklärungen sind:

Schlüsselwörter: Lunge, Lungendynamik, Neugeborenes.
1) Exzessive Zunahme des Totraums bei Fällen, in denen eine Gesichtsmaske benutzt wurde;

2) Stimulierung von Schmerzrezeptoren durch die Gesichtsmaske oder Nasenbefestigung;

3) inadäquater Zeitpunkt der Aufzeichnung.

Wie auch immer die Erklärung - unsere $\dot{V}$-Werte sollten nicht als Basis zugrunde gelegt werden, sondern sind mit Vorsicht zu interpretieren. Insgesamt ermöglicht unsere Vorarbeit, das Programm fortzusetzen und bei Neugeborenen mit RDS anzuwenden.

\section{Résumé}

Appréciation de la dynamique pulmonaire chez les nouveaux-nés normaux: méthode pneumotachographique

-Nous avons mis au point dans notre laboratoire une méthode pneumotachographique pour apprécier la dynamique pulmonaire chez les nouveaux-nés en situation critique dans les services de soins intensifs. Nous avons déterminé les valeurs normales chez 48 nouveaux-nés normaux, à terme et prématurés, avant que les résultats obtenus par cette méthode puissent être utilisés. Les poids de naissance allaient de 1200 à $4100 \mathrm{~g}$ et les âges utilisés. Les poids de naissance allaient de 1200 à $4100 \mathrm{~g}$ et les âges postnataux étaient compris entre 24 heures et 21 jours. Chez trois enfants on a réalisé deux déterminations à 7 jours d'intervalle. L'étude a été réalisée à l'aide d'un pneumotachographe mis en place sur les voies aeriennes supérieures au moyen d'un masque facial à extension ou de sondes nasales en latex. Le signal de flux aerien est intégré électroniquement au temps pour produire un signal de volume. La pression des voies aeriennes est déterminée à proximité du pneumotachographe. La pression oesophagienne est déterminée à l'aide d'un cathéter rempli d'eau installé au niveau du tiers inférieur de l'œsophage.

On a mesuré le volume respiratoire (VT), la ventilation minute $(\mathrm{V})$, la compliance dynamique $(\mathrm{C}$ dyn), les résistances pulmonaires totales (R), le travail pulmonaire total (Wt), le travail élastique (We) et le travail de résistivité au flux (WV).

On a trouvé une corrélation linéaire significative entre la $\mathrm{C}$ dyn et le poids corporel $(\mathrm{r}=0,50, \mathrm{p}<0,01)$, alors qu'il n'y a pas de corrélation significative entre le poids et le VT, la V et les R. Les valeurs de VT, V et C dyn ont été corrigées en fonction du poids corporel et les moyennes $(\overline{\mathrm{X}})$, les déviations standard (DS) ainsi que les 10èmes et 90èmes percentiles figurent sur le tableau III. X, DS et les percentiles pour $\mathrm{R}$ figurent sur le tableau III. Les WT, We et WV ont été corrigés par V, et $\mathrm{X}, \mathrm{DS}$ et les percentiles figurent sur le tableau III. Les valeurs de $\mathrm{VT} / \mathrm{Kg}, \mathrm{C}$ dyn $/ \mathrm{Kg}$ et $\mathrm{R}$ sont similaires à celles trouvées par d'autres auteurs utilisant la pneumotachographie et la plethysmographie.

Les valeurs de $\mathrm{V} / \mathrm{Kg}$ que nous avons obtenues sont supérieures à celles rapportées par d'autres auteurs ce qui, joint à l'absence de corrélation de VT et $\mathrm{V}$ avec le poids corporel, pose la question de la fiabilité des valeurs de $\mathrm{V}$ dans notre étude. Ce fait peut s'expliquer par:

1) Une augmentation excessive de l'espace mort dans les cas pour lesquels un masque facial a été utilisé.

2) Une stimulus nociceptif provoqué par le masque facial ou les sondes nasales.

3) Une sélection inadéquate du moment d'enregistrement.

Quelle que soit l'explication nos valeurs de V ne peuvent être considérées comme des valeurs de base et on doit les interpréter avec prudence. Les résultats obtenus nous autorisent à continuer notre programme et à mettre en œuvre cette méthode pour l'étude des nouveaux-nés présentant un SDR.

Mots-clés: Dynamique pulmonaire, nouveau-né, poumon.

\section{References}

[1] Barret Dahms B, A Krauss, P Auld: Pulmonary function in dismature infants. Pediatrics 84 (1974) 434

[2] Chu J, P Dawson, M Klaus, A Sweet: Lung compliance and lung volume measured concurrently in normal full term and premature infants. Pediatrics 34 (1964) 525
[3] Cook CD, J Sutherland, S Segal, R Cherry, J MeAD, MC ILroy, C Smith: Studies of respiratory physiology in the newborn infant. III Measurements of mechanics of respiration. J Clin Invest 36 (1957) 440

[4] Cunningham MD: Monitoring pulmonary function during mechanical ventilation of infants with RDS. Respir Ther (1983) 47 
[5] Hualmarson O, T Olsson: Mechanics of breathing in newborn infants III. Mechanical and ventilatory parameters in healthy and diseased newborn infants. Acta paediatr Scand [Suppl] 247 (1974) 26

[6] Karlberg P, R Cherry, F Escardo, G Koch: Respiratory studies in newborn infants. I. Apparatus und methods for studies on pulonary ventilation and the mechanics of breathing. Principles of analysis in mechanics of breathing. Acta Paediatr Scand (1960) 345

[7] KARLBERG P, G FoCH: Respiratory studies in newborn infants. III Development of mechanics of breathing during the first week of life. A longitudinal study. Acta Paediatr Scand [Suppl] 135 (1962) 121

[8] Polgar G: Airway resistance in the newborn infant. Preliminary communication. J Pediatr 59 (1961) 915
[9] Polgar G, T String: The viscous resistance of the lung in newborn infants. J Pediatr 69 (1965) 787

[10] Polgar G: Opposing forces to breathing in newborn infants. Biol Neonte 11 (1967) 1

[11] SwYer P, R ReIMAN, J Wright: Ventilation and ventilatory mechanics in the newborn. Methods and results in 15 newborns. J Pediatr 56 (1960) 612

[12] YU VY, P RoLFE: Effect of feeding on ventilation and respiratory mechanics in newborns infants. Arch Dis Child 51 (1976) 310

Received July 8, 1987. Accepted July 22, 1987.

Paul Estol, M.D.

Centro Latinoamericano de Perinatologia y Desarrollo Humano Casilla de Correo 627 Hospital de Clínicas P. 16 Montevideo, Uruguay 